\title{
MS Berlin, State Library, Glaser 51: A Unique Manuscript from the Early 7 th/13th- Century Bahšamite Milieu in Yemen
}

\author{
Hassan Ansari and Jan Thiele
}

The former Königliche Bibliothek zu Berlin—-today the Staatsbibliothek zu Berlin—was the first Western library to acquire an important collection of Yemeni manuscripts. In 1884 and 1887 , the library purchased 264 manuscripts that had been assembled by the Austrian scholar Eduard Glaser (1855-1908) during his journeys to Yemen between $1882-1884$ and $1885^{-1886 .}{ }^{2}$ The Berlin collection comprises several manuscripts of significant value, which bear witness to an important chapter in the intellectual history of Yemen in general and its Zaydī community in particular. Between the sixth/twelfth and the seventh/thirteenth centuries, Yemen became an important centre of Mu'tazilī theology. Under the reign of the Imāms al-Mutawakkil 'alā llāh Aḥmad b. Sulaymān (d. 566/1170) and al-Manșūr bi-llāh 'Abd Allāh b. Ḥamza (d. 614/1217), the doctrines of the Bașran Mu'tazilite school were officially promoted, while, at the same time, other forms of Zaydì theology were increasingly marginalised. At the initiative of the two imāms, numerous books, including many Mu'tazilite texts, were transmitted to Yemen, thus laying the foundation for some of the country's richest manuscript collections.

Among the manuscripts of the Berlin collection that date back to this period is the codex Glaser 51.

\footnotetext{
${ }^{1}$ Hassan Ansari would like to thank the Institute for Advanced Study, Princeton for hosting him while this chapter was finalised; his special thanks go to Patricia Crone for her support during his membership. Jan Thiele would like to thank the Gerda Henkel Foundation for granting him an M4Human Fellowship during the preparation of this chapter.

${ }^{2}$ Eduard Glaser acquired two further collections of manuscripts during his third and fourth journeys to Yemen, in 1887-1888 and 1892-1894, which he sold to the British Museum in London and the Austrian National Library in Vienna. For further details see Sabine Schmidtke, "The History of Zaydī Studies: An Introduction", Arabica 59 (2012), p. 187.
} 
It contains the third volume of a work entitled Kitāb al-Tafṣ̂ll li-ğumal al-Taḥṣil, written by Sulaymān b. 'Abd Allāh al-Hูurāšî. ${ }^{3}$ The Kitāb al-Tafṣ̂ll is the earliest of at least three commentaries on the Kitāb al-Tahṣil fil-l-tawhìd wa-l-ta'dīl, ${ }^{4}$ a comparatively short theological compendium written by al-Ḥasan b. Muhammad al-Rașșāṣ (d. 584/1188). Al-Rașṣāṣ was one of the most important Zaydī theologians of sixth/twelfth-century Yemen, who followed Bahšamite doctrines. ${ }^{5}$ Apparently the copy of the Kitāb al-Tafṣil that is preserved in Berlin is a unique manuscript and also the only part of the work that has survived. Through analysing the notes on the manuscript, written by a scribe and its original owner, we can gain new insights into the milieu of early seventh/thirteenth-century scholarship in Yemen. The text of the Tafṣill ends with a colophon by the copyist—who gives his name as Ḥusayn b. 'Awāḍ b. 'Alī—in which says he completed this volume sometime between the tenth and twentieth of Dū al-Qa'da 610/1214. ${ }^{6}$

The title page contains a note, possibly written by another hand, stating that the copy was made

${ }^{3}$ The manuscript was published as Sulaymān b. 'Abd Allāh al-Hูurāšī, Kitāb al-Tafșill li-ğumal alTahșīl. Facsimile Edition of MS Berlin, Glaser no. 51. With Introductions and Indices by Hassan Ansari and Jan Thiele, Tehran, Mīrāt-i maktūb and Freie Universität Berlin, 2013.

${ }^{4}$ For the commentaries on al-Rașșāṣ’s Kitāb al-Taḥșill, see Jan Thiele, "Theological Compendia in Late 6th/12th and Early 7th/13th Century Zaydism: al-Hasan al-Rașsāạs's K. al-Tahṣill and Its Commentaries", in Theological Rationalism in the Medieval World of Islam: New Texts and Perspectives, ed. G. Schwarb, S. Schmidtke, and L. Mühlethaler, Leuven, Peeters [in press]. ${ }^{5}$ For al-Rașsāṣ, see Hassan Ansari, "Al-Barāhīn al-zāhira al-jaliyya 'alā anna l-wujūd zā'id 'alālmāhiyya, by Ḥusām al-Dīn Abū Muḥammad al-Ḥasan b. Muḥammad al-Raș̣̣aṣ", in A Common Rationality: Mu'tazilism in Islam and Judaism, ed. C. Adang, S. Schmidtke, and D. Sklare, Würzburg, Ergon, 2007, p. 337-48; Jan Thiele, "Propagating Mu'tazilism in the VIth/XIIth Century Zaydiyya: The Role of al-Ḥasan al-Rașṣāṣ", Arabica 57 (2010), p. 536-558; idem, Kausalität in der mu'tazilitischen Kosmologie: Das Kitāb al-Mu'aț-irät wa-miftāḥ al-muškilāt des Zayditen al-Hasan ar-Rașșāṣ (st. 584/1188), Leiden, Brill, 2011; idem, Theologie in der jemenitischen Zaydiyya: Die naturphilosophischen Überlegungen des al-Hasan ar-Rașsāạ, Leiden, Brill, 2013.

${ }^{6} \mathrm{Cf}$. the colophon on f. 186b (see also below Plate Two):

$$
\text { فرغ من نساخته الفقير إلى رحة ربّه حسين بن عواض بن علي يوم الخميس بواقي عشر واثنتين ( كذا :الإثنين) من ذي }
$$


for the library of Tāğ al-Dīn Aḥmad b. Muhammad b. Aḥmad b. Yahyā b. Yahyyā (d. 644/1247).7 The said Tāğ al-Dīn belonged to a noble Zaydī family. ${ }^{8}$ He succeeded his brother Mağd al-Dīn Yaḥyā b. Muhammad (d. 607/1210-1) as amīr of Șa da and Nağrān, a position he held even beyond the death of Imām al-Manșūr bi-llāh 'Abd Allāh b. Ḥamza, in 614/1217. His father, Badr al-Dīn Muhạammad b. Aḥmad b. Yahyyā b. Yaḥyā (d. 624/1227), and his uncle, Šams al-Dīn Yaḥyā b. Aḥmad b. Yahyā b. Yahyā (d. 606/1209-10), had already supported al-Manșūr bi-llāh's claim to the imamate-. Tāğ alDīn's brother al-Ḥasan b. Badr al-Dīn (d. 670/1272) was eventually recognised as imām, taking the title of al-Manșūr.

In addition to the family's political role, several of its members were renowned scholars. Tãğ alDīn's third brother, al-Ḥusayn b. Badr al-Dīn (d. 662/1264 or 663/1265), was a prolific author of works on religious scholarship. Among his most important works are Šifä́ al-awāmm fì ahâadīt al$a h k a \bar{m} m^{9}$ and Yanābī al-nașịha fí l-'aqā̉id al-șaḥịha. ${ }^{10}$ Tāğ al-Dīn himself reportedly wrote several

${ }^{7}$ See f. 1a (see also below Plate ONE):

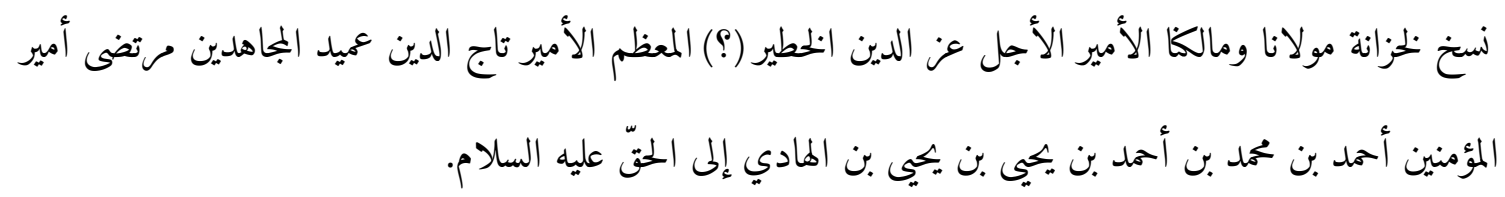

${ }^{8}$ Information on some prominent members of the family is found in Ḥumayd b. Aḥmad al-Muhallī, al-Hadā’iq al-wardiyya fı manāqib a’immat al-Zaydiyya [Facsimile Edition], Șan'ā’, Tawzì` al-Sayyid Ḥusayn al-Sayyānī al-Ḥasanī, 1982, vol. 2, p. 195; Muhammad b. 'Alī b. Yūnis al-Zahịif Ibn Fand, Ma'ātir al-abrār fì tafṣ̂l muğmalāt ğawāhir al-ahbār: Wa-yusammā l-Lawāhniq al-Nadiyya bi-lHadā’iq al-wardiyya 1-3, ed. 'Abd al-Salām b. 'Abbās al-Wağīh, Șan'ā’, Mu'assasat al-Imām Zayd b. 'Alī al-țaqāfiyya, 1423/2002, vol. 2, p. 817-818, 823-834, 887-898; Aḥmad b. Ṣāliḥ Ibn Abī l-Riğāl, Mațla' al-budūr wa-mağma' al-buhūr fì tarāğim riğāal al-Zaydiyya 1-4, ed. 'Abd al-Raqīb Muṭahhar Muḥammad Ḥağar and Mağd al-Dīn b. Muḥammad b. Manșūr al-Mu'ayyidī, Ṣa'da, Markaz Ahl alBayt li-l-dirāsāt al-islāmiyya, 2004/1425, vol. 1, p. 408, vol. 2, p. 215-217, vol. 4, p. 174-175, 483-484, 511; and Ibrāhīm b. al-Qāsim al-Šahārī, Ṭabaqāt al-zaydiyya al-kubrā (al-qism al-tālitit) wa-yusammā Bulūg al-murād ilā ma'rifat al-isnād 1-3, ed. 'Abd al-Salām b. 'Abbās al-Wağīh, McLean, VA, Mu’assasat al-Imām Zayd b. 'Alī al-țaqāfiyya, 1421/2001, p. 327-329, 383-388, 909-912, 1201-1203.

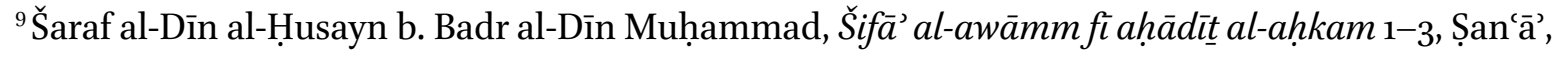
Ǧam'iyyat 'Ulamā' al-Yaman, 1416/1992-3.

${ }^{10}$ Šaraf al-Dīn al-Ḥusayn b. Badr al-Dīn Muḥammad, Yanābíc al-naṣịha fí l-'aqā’id al-ṣaḥịha, ed. al- 
works on legal methodology and theology, none of which, however, are known by title." Very little is known about the author of the Tafṣ̂l, which is preserved in MS Glaser 51. Al-Hurāšìs nisba derives from the name of a small village called Hurāša, which is situated to the west of 'Ans, in the province of Damār. The Banū al-Hurāšs̄ clan was renowned for the many prominent judges it produced..$^{12}$ In the bio-bibliographical literature, only Ibn Abī l-Riğâl's Mațlac al-budūr contains a short entry on Sulaymān b. 'Abd Allāh al-Hurāšī. All it reveals is that he was an important scholar of his time and the teacher of a certain 'Alī b. Hamīs. ${ }^{13}$

In addition, al-Hurāšì is briefly mentioned in the entry on Muḥammad b. al-Amīr al-Muqtadir (d. 720/1320) in Tabaqāt al-Zaydiyya al-kubrā. Along with other scholars of his time, he is reported to have left his notes (hațt) in a manuscript containing Mağmū' al-fiqh li-Zayd b. 'Alī and 'Ulüm $\bar{A} l$ Muḥammad [=Amālī Aḥmad b. ' $\bar{I} s \bar{a} b$. Zayd]. ${ }^{14}$ Some of the personalities listed in this note are among the most important scholars of late sixth/twelfth and early seventh/thirteenth-century Yemen, including al-Ḥasan al-Rașṣậ, al-Amīr al-Ḥusayn b. Muḥammad, al-Hādī b. Tāğ al-Dīn (d. 7th/13th c.), and Yahyyā b. Ğābir (alive 620/1223).

In the Tafṣill, al-Hูurāšī refers to al-Rașṣāṣ as his teacher, whose lessons he attended. ${ }^{15}$ These are clear indications that al-Hurāš̄̄ attended al-Rașsāṣ's study circles in Hiğrat Sanā̄e, which is a small village that has now become a suburb of the modern capital, Șan'ā’. Al-Hurāšs̄ was still alive in 610/1214, when the Berlin manuscript of the Kitāb al-Tafṣil was copied, as the scribe commends alHurāšs̄ with the phrase "waffaqahu llāh bi-țā'atihi”."

Murtaḍā b. Zayd al-Maḥațwarī, Șan`ā’, Maktabat Badr li-l-ṭibā‘a wa-l-našr wa-l-tawzīc', 1422/2001.

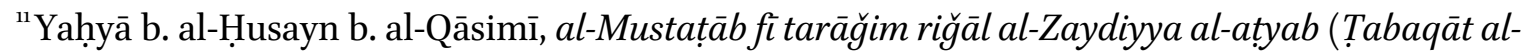
Zaydiyya al-ṣugrrā), MS Șan'ā’, Maktabat Muḥammad b. Muḥammad b. al-Manșūr, f. 7lb.

${ }^{12}$ Ismācill b. 'Alī al-Akwa', Hiğar al-'ilm wa-ma'āqiluhu fíl-Yaman 1-6, Beirut/Damascus, Dār al-fikr al-mu'āșir, 1416-1424/1995-2003, vol. 1, p. 570-571; Muḥammad b. Aḥmad al-Ḥağarī, Mağmū' buldān al-Yaman wa-qabā’ilihā 1-4, ed. Ismāềl b. 'Alī al-Akwa', Șan'ā', Maktabat al-iršād, 1430/2009, vol. 1, p. 305 .

${ }^{13}$ Ibn Abī l-Riğāl, Mațla' al-budūr, vol. 2, p. 357.

${ }^{14}$ See al-Šahārī, Țabaqāt, p. 1088f.

${ }^{15}$ See f. $74 a$ and f. $147 b$.

${ }^{16}$ See f. 1a. 
Some further information on al-Hurāšs̄ is provided by a yet unidentified manuscript on legal methodology (ușül al-fiqh), which is also found in the Berlin Glaser collection (no. 171). ${ }^{17}$ This manuscript was possibly written by the same scribe who copied al-Hurāšs̀'s Tafṣill. The text, incomplete at the beginning and therefore lacking the title and attribution to the author, largely reproduces the text of al-Manșūr bi-llāh 'Abd Allāh b. Ḥamza's Șafwat al-ihtiyār , together with further comments. ${ }^{18}$ It therefore fits a historical desciption of the presumably lost Kitāb al-Hāsṣir fi uṣūl al-figh by Aḥmad b. 'Uzayyw b. 'Alī al-Ḥuwālī al-Ḥimyarī (d. ca. 650/1252), which is said to be a text on legal methodology based on al-Manșūr bi-llāh's Ṣafwat al-ihtiya $\bar{a} \cdot{ }^{19}$ Nonetheless, we have to be cautious about identifying our manuscript with al-Ḥimyarīs work. According to Aḥmad b. Sa'd al-Dīn al-Miswarī’s Mağmū' $a l-i g ̌ a z z a \bar{a} t,{ }^{20}$ the colophon of the Kitāb al-Hāṣir should read as follows:

$$
\begin{aligned}
& \text { قال الفقيه أحمد بن عزيو رحمه الله في آخر هذا الكناب: تمّ ذلك بحمد الله ومنه وتوفيقه ولطفه في شهر رمضان المعظم سنة }
\end{aligned}
$$

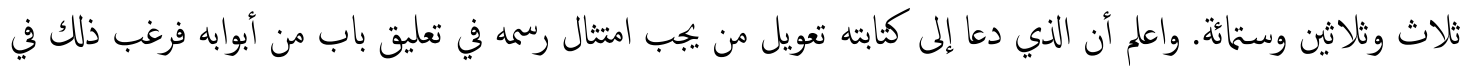

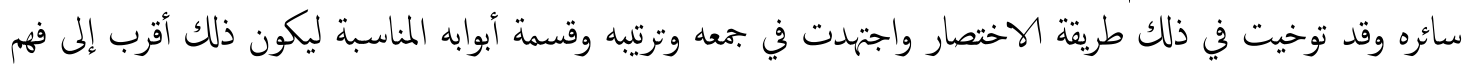

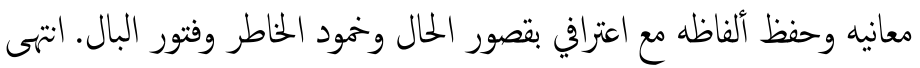

MS Staatsbibliothek zu Berlin, Glaser 171, f. 197a ends, however, with a different wording ${ }^{21}$ :

\footnotetext{
${ }^{17}$ See for the manuscript, see Wilhelm Ahlwardt, Verzeichniss der arabischen Handschriften der Königlichen Bibliothek zu Berlin 1-10, Berlin, Schade, 1887-1899, vol. 4, p. 462; and idem, Kurzes Verzeichniss der Glaser'schen Sammlung arabischer Handschriften, Berlin, Unger, 1887, p. 29-30. He erroneously identifies the text as al-Hurāššs al-Tafṣ̂ll.

${ }^{18}$ al-Manșūr bi-llāh ‘Abd Allāh b. Ḥamza, Șafwat al-ihtiyār fì uṣūl al-fiqh, ed. Ibrāhīm Yahyā alDarasī al-Ḥamzī and Hādī b. Ḥasan b. Hādī al-Ḥamzī, Ṣa‘đda, Markaz Ahl al-Bayt li-l-dirāsāt alislāmiyya, 1423/2002.
}

${ }^{19}$ See the relevant passage in the sīra of the Imām al-Mahdī li-Dīn Allāh Aḥmad b. al-Ḥusayn b. alQāsim (d. 656/1258), edited and commented upon in Hassan Ansari and Sabine Schmidtke, "The Literary-Religious Tradition among 7 th/13th Century Yemeni Zaydīs: The Formation of the Imām al-Mahdī li-Dīn Allāh Aḥmad b. al-Ḥusayn b. al-Qāsim (d. 656/1258)", Journal of Islamic Manuscripts 2/2 (2011), p. 177, 185. Gregor Schwarb has also suggested that the manuscript should be identified as al-Himyarî’s al-Hāạsir (personal communication).

${ }^{20}$ Aḥmad b. Sa'd al-Dīn al-Miswarī, Mağmū' al-iğ $\bar{a} z a \bar{t} t$, scan in MAS Maktabat 'Abd al-Raḥmān àŠāyim, p. 424.

${ }^{21}$ See also below Plate Four. 


$$
\text { تمت مسائل هذا الخختصر | والمحد لله وحده وصلواته | على رسوله سيدنا محد وآله | حسبنا الله وكفى }
$$

Therefore, another possible hypothesis for the identity of the fragment could be that MS Glaser 171 is in fact Tāğ al-Dīn Aḥmad b. Badr al-Dīn's abovementioned work on uṣūl al-fiqh. Ḥusayn b. 'Awāḍ b. 'Alī, who copied the manuscript of the Tafṣ̂ll for Tãğ al-Dīn, could then have also been commissioned by his patron to produce this fair copy of this work.

Our particular interest in this text on ușūl al-figh consists in the fact that the anonymous author states that he attended the classes taught by al-faqīh Nūr al-Dīn Sulaymān b. 'Abd Allāh al-Hurāšs̄ì. ${ }^{22}$ The title al-faqīh suggests that al-Hurāšī was also an authority on juridical questions. With regard to al-Hurāššs's identity, the anonymous text raises additional questions, however. The author repeatedly refers to al-faqīh Nūr al-Dīn Sulaymān b. 'Abd Allāh al-Sufyānī, whose lessons he claims to have attended as well. ${ }^{23}$ Further references in the manuscript are made to šayhunā l-faqīh Nūr alDīn Sulaymān b. 'Abd Allāh, ${ }^{24}$ or simply Nūr al-Dīn. ${ }^{25}$ In these cases, it remains unclear to which of

\footnotetext{
${ }^{22}$ See f. 2ob: huwa llad̄i kāna yaqūl bihi šayhunā al-faqīh Nūr al-Dīn Sulaymān b. 'Abdallāh al-Hurāš̄ rahimahu llāh fì waqt al-dars.

${ }^{23}$ See f. 38a: wa-huwa llad̄ī rağğaḥahu l-šayh Abū 'Alī al-Ḥasan b. Muḥammad al-Rașșāṣ radya llāh

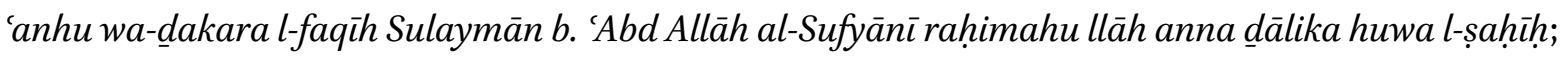
ff. 39b-40a: wa-kāna al-šayh Abū 'Alì al-Hasan b. Muhammad al-Rașșāṣ raḍya llāh 'anhu yaḍabu ilā l-qawl al-awwal fì-mā ḥakāhu l-faqīh Nūr al-Dīn Sulaymān b. 'Abd Allāh al-Sufyānī rahimahu llāh

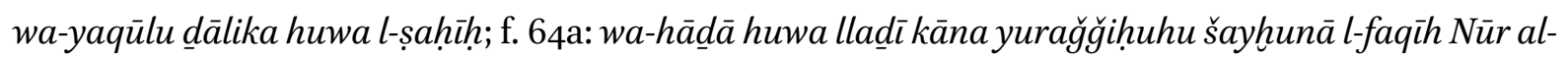
Dìn Sulaymān b. 'Abd Allāh al-Sufyānī raḥimahu llāh; f. 70a-b: wa-h̆tārahu l-faqūh Nūr al-Dīn
} Sulaymān b. 'Abd Allāh al-Sufyānī rahịimahu llāh; ff. 73b-74a: 'alā mā kāna yaḥkīhu l-faqīh Nūr alDìn Sulaymān b. 'Abd Allāh al-Sufyānī 'an al-šayh Abī 'Alī l-Rașṣāṣ raḍiya llāh 'anhu wa-yuḥkā 'an Abī Rašìd wa-l-Ṣăḥib...; f. 8ob: wa-llad̄i ḥakaynāhu 'an šayhinā Nūr al-Dīn Sulaymān b. 'Abd Allāh alSufyānī wa-ra'aynāhu bi-hnaț̣ihi fì ba'ḍ tașānīfihi...; f. 85a: wa-llad̄ì kāna yaqūl bihi l-faqūh Nūr al-Dìn Sulamyān b. 'Abd Allāh al-Sufyānī wa-hașsalahu lanā fì l-dars.

${ }^{24}$ See f. 3a: huwa llad̄i hntārahu al-faqīh Nūr al-Dīn Sulaymān b. 'Abd Allāh wa-hakāhu 'an al-šayh Abì 'Alī al-Hasan b. Muhammad al-Rașșāṣ raḍa llāh 'anhu; f. 26b: wa-hāḍā l-qawl allad̄ì kāna yaqūlu bihi šayhunā l-faqūh Nūr al-Dīn Sulaymān b. 'Abd Allāh rahịmahu llāh waqt al-dars; f. 35b: hādāa llad̄i ḥafaznāhu 'an šayhunā l-faqūh Nūr al-Dīn Sulaymān b. 'Abd Allāh rahịmahu llāh waqt al-dars; f. 86b: fì-mā dِakarahu šayhunā l-faqīh Nūr al-Dīn Sulaymān b. 'Abd Allāh.

${ }^{25}$ See ff. 91b-92a: ḥafaznāhu 'an šayhunā l-faqīh Nūr al-Dīn raḥimahu llāh waqt al-dars; f. 137a: 
his teachers the author refers. It appears, however, unlikely that both mentions of Sulaymān b. 'Abd Allāh refer to one and the same person rather than to contemporary namesakes. As a member of the Sufyān tribe, Sulaymān b. 'Abd Allāh al-Sufyānī hailed from Bikīl. His hometown was Šuwāba which is situated north-west of Șan`ā’, while Hurāša is situated in the south of Șan`ăa. ${ }^{26}$ Unlike al-Hुurāšī, who harshly criticised al-Manșūr bi-llāh's politics, al-Sufyānī is known to have been a follower of the Imām who appointed him governor of Bikil, the region he came from. ${ }^{27}$ Aside from this administrative position, al-Sufyānī is known as a scholar who taught the later Imām al-Dācī al-Mu'taḍid bi-llāh Yaḥyā b. al-Muḥsin b. Abi l-Fawāris Maḥfūẓ (d. 636/1238-9) in uṣūl al-dīn and uṣūl al-fiqh. ${ }^{28}$ Al-Sufyānī was still alive in 6oo/1203. ${ }^{29}$

Over the course of the time, al-Hurāšǐs Kitāb al-Tafșill li-ğumal al-Taḥșil appears to have been forgotten by Zaydī scholars. Although his commentary was an extensive and sophisticated work, the title does not figure in the bio-bibliographical literature. As far as we know now, the only historical source that mentions the text is a list of titles possessed by a seventh/thirteenth-century

šayhunā Nūr al-Dīn raḥimahu llāh; f. 137b: wa-hādā ḩtiyār šayhunā Nūr al-Dīn.

${ }^{26}$ For the Sufyān tribe see al-Ḥağarī, Mağmū‘ buldān al-Yaman, vol. 2, p. 424-426; Ibrāhīm alMaqḥafī, Mawsū'at al-alqāb al-Yamaniyya 1-7, Beirut, al-Mu’assasa al-Ǧāmi'iyya li-l-dirāsāt wa-lnašr wa-l-tawzī', 1431/2010, vol. 2, p. 892-894.

${ }^{27}$ See Abū Firās Ibn Di'țam, al-Sìra al-šarīfa al-manșūriyya. Sìrat al-imām 'Abd Allāh b. Hamza 1-2, ed. 'Abd al-Ġanī Maḥmūd 'Abd al-'Āṭī, Beirut, Dār al-fikr al-mu'āṣir, 1414/1993, p. 179-18o, 306f.; alManșūr bi-llāh 'Abd Allāh b. Ḥamza, Mağmū'mukātabāt, ed. 'Abd al-Salām 'Abbās al-Waǧīh, 'Ammān, Mu’assasat al-imām Zayd b. 'Alī al-țaqāfiyya, 2008, p. 78f., 33of.; Ibn Abī l-Riǧāl, Maṭla a albudūr, vol. 2, p. 357; Yaḥyā b. al-Ḥusayn b. al-Qāsimī, Mustațāb, f. 69a. For al-Hुurāšǐs position towards al-Manșūr bi-llāh, see al-Hādì b. Ibrāhīm al-Wazīr, Kāšifat al-ġumma 'an ḥusn sīrat imām al-a’imma, scan in Maktabat 'Abd al-Raḥmān Šāyim, p. 36.

${ }^{28}$ al-Šahārī, Ṭabaqāt, p. 1249.-For al-Sufyānī’s scholarly reputation see also Ibn Abī l-Riǧāl, Maṭla al-budūr, vol. 2, p. 357, no. 634; Yahyyā b. al-Ḥusayn b. al-Qāsimī, Mustațāb, f. 69 a.

${ }^{29}$ Abū Firās Ibn Di'tam, Sìra, p. 306-307. The first part of Ibn Di'tam's al-Sìra al-manșūriyya has been recently rediscovered by Hassan Ansari (cf. Hassan Ansari, "Du ǧild tāze-yāb-i sīre-ye Manșūr bi-llāh" [http://ansari.kateban.com/entry2096.html]); additional information on al-Sufyānī is found in these parts of the work. 
collector of books, Yaḥyā b. Ǧābir. ${ }^{30}$

The extant third part of the Tafṣil-comprising the last subheadings of the chapter on God's justice, the parts on prophecy and the Qur'ān, and the beginning of the chapter on the imamatecomments on the third quarter of al-Rașșāș's book. This suggests that the whole work was originally comprised of four parts. The fourth volume announced in the colophon (f. 186b) would thus be the last book of the text. Al-Hurāšì's commentary must have exceeded by far the extent of the original text by al-Rașșāṣ. Comparable in size to Ibn Mattawayh's al-Mağmūc fí l-Muhịt bi-ltaklîf, the original Tafṣil was likely the most extensive Bahšamī compendium of al-Hurāššs time composed in Yemen. None of the previous representatives of the school had completed a theological summa of comparable size.

Almost the entire text of Rașșāș's Kitāb al-Tahṣ̂̄l is embedded in the Tafṣ̂ll and further elaborated on by al-Hurāšì's explanations. The two layers of text are not, however, formally separated (e.g. by introductory formulas) and are therefore indistinguishable, unless examined side by side. As a typical pattern, the chapters of the Tafșill begin with an introductory formula such as faṣl fi .../fașl wa-ttașala bi-hadihi l-ğumla al-kaläm fi .../faṣl wa-l-garad bihi l-kalām $f i$..., followed by the title as formulated in al-Rașṣāṣ's text. Al-Hुurāšī usually tends to subdivide al-Rașṣāṣ's original chapters into several mawädic that are listed immediately after the chapter heading. Over the course of the text, verbatim quotes from the Kitāb al-Tahșīl are interwoven with al-Hurāššss explanations. Al-Hurāšs̀'s commentary has, with few exceptions, the same chaptering as al-Raș̣āș’s Kitāa alTahṣill. The rare changes introduced by al-Hurāšì do not, however, affect the structure set by the Kitāb al-Tahșill. Rather, he follows the chronological order of the text being commented upon, adding — sometimes extensively—new aspects that were not covered in the Kitāb al-Tahṣill. In alRașșāș's text, the chapter on prophecy (al-qawl fi l-nubuwwa) is subdivided into several fușūl, with the exception of the section on the proof for Muhammad's prophecy, which is labelled as a

\footnotetext{
${ }^{30}$ An illustration of this list, contained in MS Milan, Ambrosiana ar. E 208, f. 61a (dated 620/1223), can be found in Oscar Löfgren and Renato Traini, Catalogue of the Arabic Manuscripts in the Biblioteca Ambrosiana 1-4, Vicenza/Cinisello Balsamo, Neri Pozza/SilvanaEditoriale, 1975-2011 vol. 3 between p. 138 and 139. See also Hassan Ansari and Sabine Schmidtke, "Mu'tazilism in Rayy and Astarābād: Abū l-Fạ̣l al-'Abbās b. Sharwīn (Studies on the Transmission of Knowledge from Iran to Yemen in the 6th/12th and 7th/13th C., II)", Studia Iranica 41 (2012), p. 66 n. 48.
} 
separate $b \bar{a} b$. Al-Hurāšs̄ possibly intended to avoid potential misunderstandings and therefore renamed all subsections mawā $\mathfrak{d i}^{\text {, }}$, including the section on the proof for Muhammad's prophecy, in order to indicate that it belongs thematically to the $b \bar{a} b$ al-qawl fi l-nubuwwa (see f. 37b: bāb fi it $b \bar{a} t$ nubuwwat Muḥammad [...] wa-huwa l-mawḍi al-rābic min al-kalām fí l-nubuwwāt). In the Faṣl fí lQur'ān, al-Hurāšī introduces two new subsections (ff. 88b and 101a), which in al-Rașsāṣ's original text were interjections in the typical dialectic fa-in qüla ... qulnā ... style. In the chapter on the imamate, the content of al-Rașșāṣ's first subsection (fașl fíl-imāma wa-mā hiya wa-fí wuğūbihā wafi bayān al-garaḍ bihā) is further divided by al-Hurāšñ into four subheadings (i.e. the first four fuṣūl of the chapter).

Al-Hurāšī used for his commentary sources that had not been consulted by al-Rașạāṣ for the

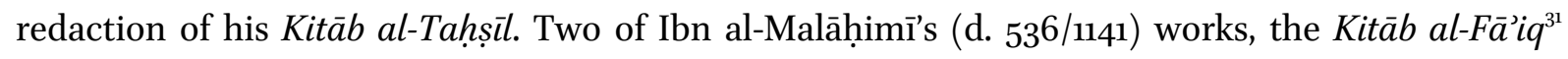
and the Kitāb al-Mu'tamad, ${ }^{32}$ are quoted only in the Kitāb al-Tafșill. Ibn al-Malāḥimī was a representative of the school of Abu l-Ḥusayn al-Bașin̄ (d. 436/1044), who had studied with Qāḍī 'Abd al-Ǧabbār and who disagreed on various theological issues with Bahšamī teachings. Al-Rașsāạs was familiar with Abu l-Ḥusayn's thought, but there is no evidence that he knew Ibn al-Malāhimì’s writings, aside from his Tuhfat al-Mutakallimin fíl-radd 'alä l-falāsifa, a section of which he refuted in his al-Barāhīn al-zāhhira al-ğaliyya 'alā anna l-wuğūd za'id 'alā l-māhiyya. ${ }^{33}$ In various instances, al-Hurāšs̄ explicitly refers to Ibn al-Malāḥimī and/or his writings to highlight specific

\footnotetext{
${ }^{31}$ Rukn al-Dīn Ibn al-Malāḥimī al-Hูwārazmī, Kitāb al-Fā’iq fì uṣūl al-dīn, ed. Wilferd Madelung and Martin McDermott, Tehran, Iranian Institute of Philosophy and Institute of Islamic Studies, Free University Berlin, 2007.

${ }^{32}$ Rukn al-Dīn Ibn al-Malāḥimī al-Ḩwārazmī, Kitāb al-Mu'tamad fì uṣūl al-dīn, ed. Wilferd Madelung, Tehran, Mīrāt-i Maktūb and Freie Universität Berlin, 2012.

${ }^{33}$ Ansari, "Al-Barāhīn al-zāhira"; idem, "Maḥmūd al-Malāḥimī l-Mu'tazilī fì Yaman wa-ta 'rīf bi-risāla fì l-radd 'alayhi ḥawla ziyādat al-wuğūd 'alā l-māhiyya”, al-Masār 11 (2010), p. 48-58. For the Tuhfa, see Rukn al-Dīn Ibn al-Malāḥimī al-Ḩwārazmī, Tuhffat al-mutakallimīn fì l-radd 'alā l-falāsifa, ed. Hassan Ansari and Wilferd Madelung, Tehran, Iranian Institute of Philosophy and Institute of Islamic Studies, Free University Berlin, 2008; Wilferd Madelung, "Ibn al-Malāḥimī’s Refutation of the Philosophers", in A Common Rationality: Mu'tazilism in Islam and Judaism, ed. C. Adang, S. Schmidtke, and D. Sklare, Würzburg, Ergon, 2007, p. 331-336.
} 
disagreements with his school. In the chapters on prophecy and the imamate, however, al-Hurāšĩ without comment inserts lengthy literal quotations from the Kitāb al-Fà̃ $i q$, with no mention of the fact that he had used the text as a source for this chapter. ${ }^{34}$ Al-Hurāšs's Kitāb al-Tafșill is therefore one of the earliest known Zaydī sources attesting to the transmission of the Kitāb al-Fā̄iq and Kitāb al-Mu'tamad to Yemen as well as to the impact of Ibn al-Malāhimī’s teachings on Zaydī theological thought.

The manuscript of the Kitāb al-Tafṣil was bound after it had been transferred to Berlin. The cover carries the Prussian eagle of the former Königliche Bibliothek zu Berlin. As already mentioned by Ahlwardt in the Berlin catalogue, leaves $59-70$ are misplaced and have their correct location between ff. $130 \mathrm{~b}$ and $131 \mathrm{a}^{35}$

\section{Appendix}

In the following table of contents of al-Hुurāšì's Kitāa al-Tafșill, the chronological order of the text has been restored. It provides the folio numbers of the original manuscript and the corresponding pages in the facsimile edition in square brackets.

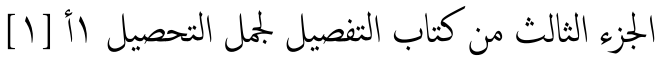

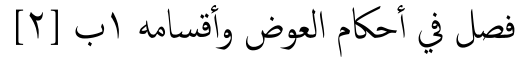

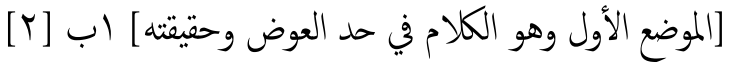

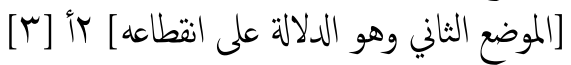

$$
\begin{aligned}
& \text { [الموضع الثالث وهو أن العوض قد يجب عليه تعالى وإن كان الألم من غيره] }
\end{aligned}
$$

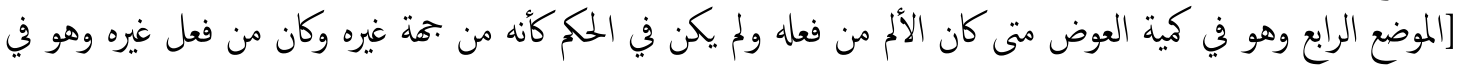

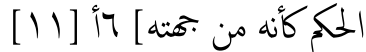

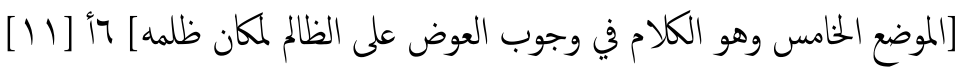

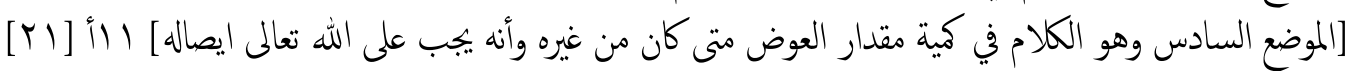

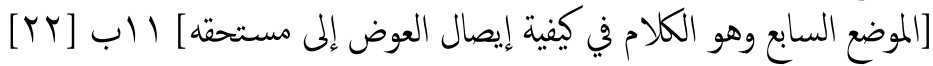

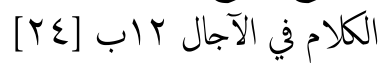

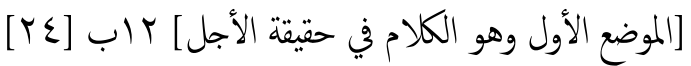

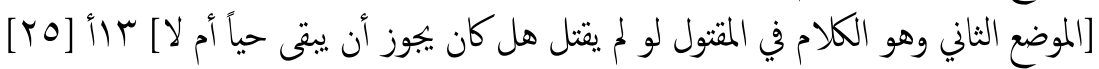

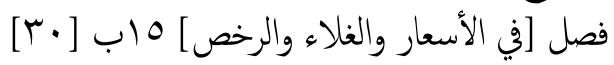

\footnotetext{
${ }^{34}$ Al-Hurāš̀ mentions the Kitāb al-Fā’iq only once (f. 127b), while most of the quotations are not marked as such; see Thiele, "Theological Compendia".

${ }^{35}$ See Ahlwardt, Verzeichniss, vol. 9, p. 588.
} 
[الموضع الأول وهو الكلام في معاني السعر والغلاء والرخص] 7 أ [أ [ابـ]

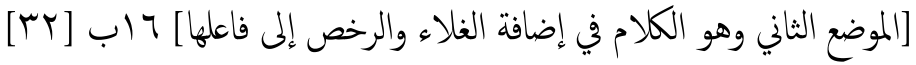

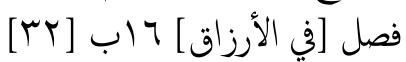

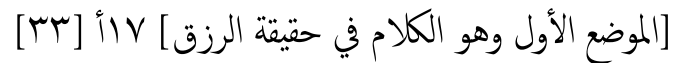

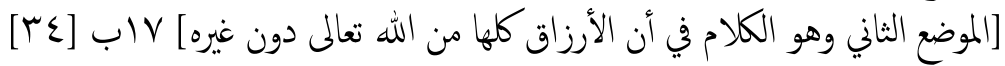

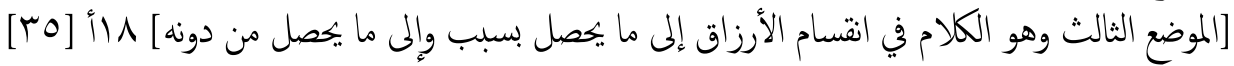

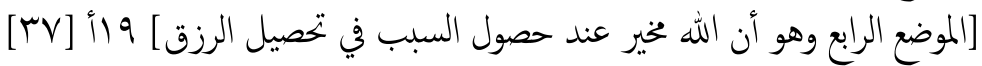

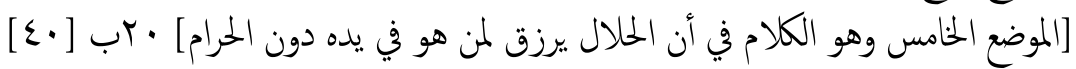

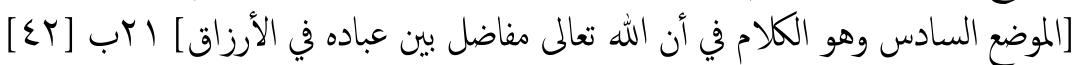

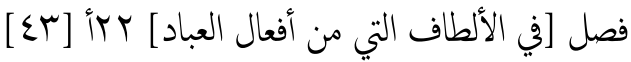

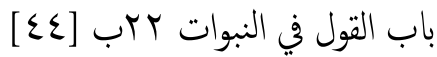

[الموضع الأول وهو الكلام في معنى قولنا رسول الله ونبي الله وفي الصفات التي يجب أن يكون عليها النبي صلى الله عليه]

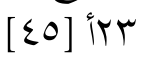

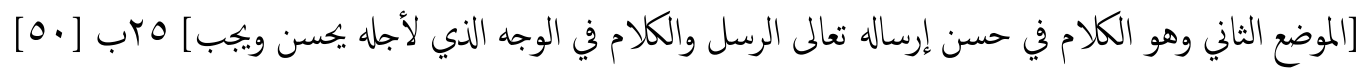

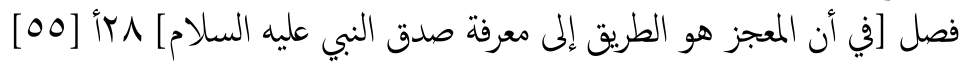

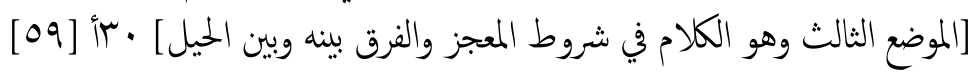

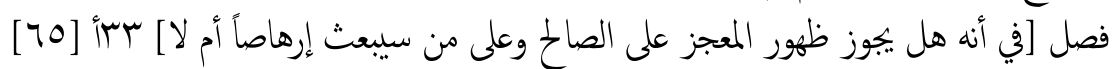

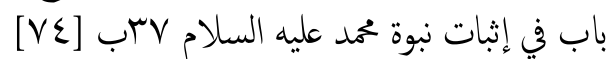

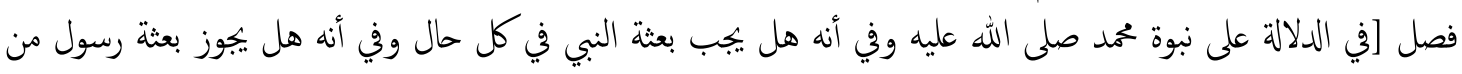

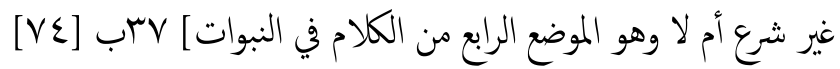

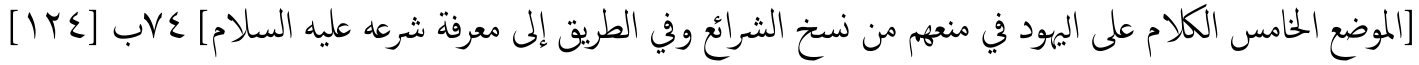

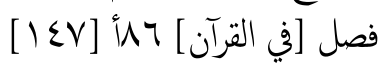

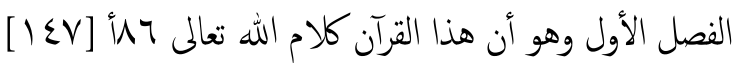

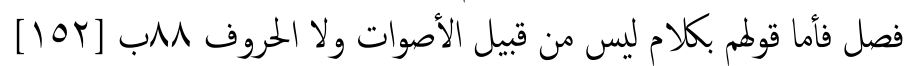

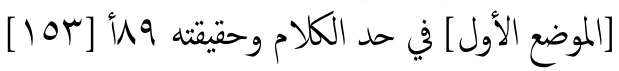

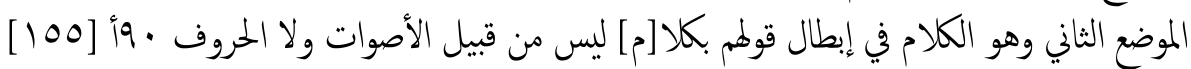

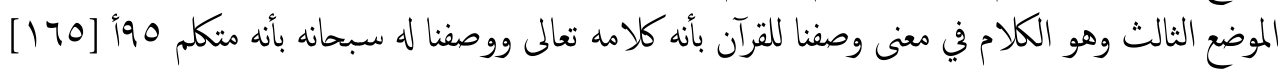

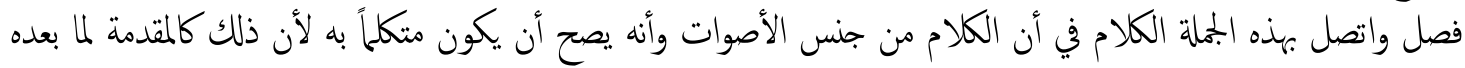

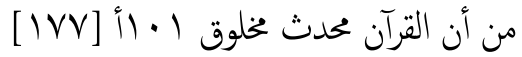

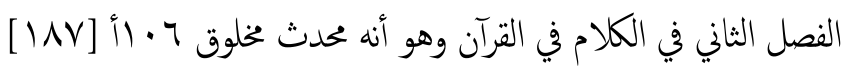

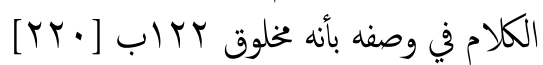

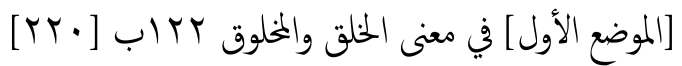

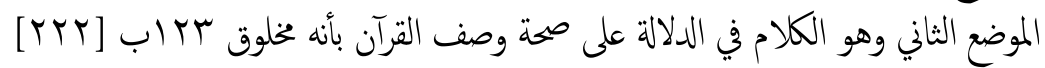

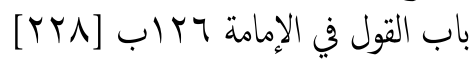

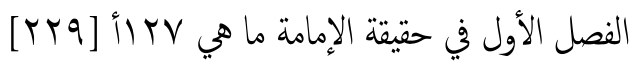

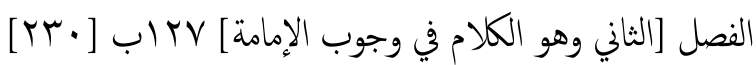

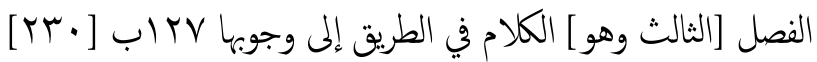

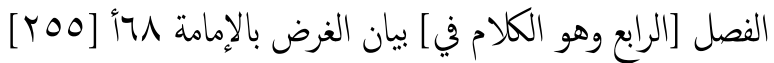




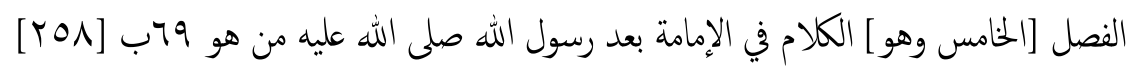

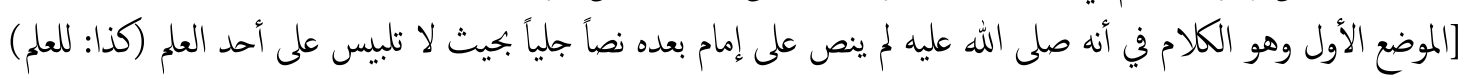

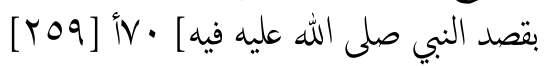

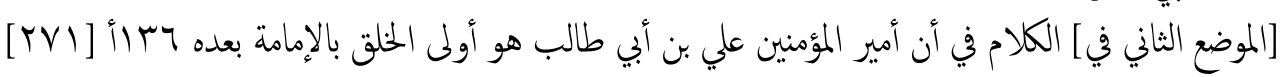

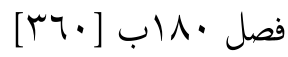




\section{[ADD PLATE ONE]}

PLATE ONE: MS Staatsbibliothek zu Berlin, Glaser 51, f. 1a (@ Staatsbibliothek zu Berlin; with kind permission)

\section{[ADD PLATE TWO]}

Plate Two: MS Staatsbibliothek zu Berlin, Glaser 51, f. 186b (@) Staatsbibliothek zu Berlin; with kind permission)

\section{[ADD PLATE THREE]}

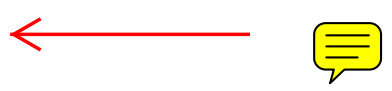

PLATE Fmef: MS Staatsbibliothek zu Berlin, Glaser 171, f. 197a ( Staatsbibliothek zu Berlin; with kind permission) 